U. S. DEPARTMENT OF COMMERCE

Bureau of Standards JESSE H. JONES, Secretary

NATIONAL BUREAU OF STANDARDS

MAY $8: 1943$

LYMAN J. BRIGGS, Director

\title{
METHODS OF ANALYSIS AND OF REPORTING FIBER COMPOSITION OF TEXTILE PRODUCTS
}

(SECOND EDITION)

\section{COMMERCIAL STANDARD CS65-43}

Supersedes CS65-38

Effective as a Basis for Analyzing and Reporting From February 20, 1943

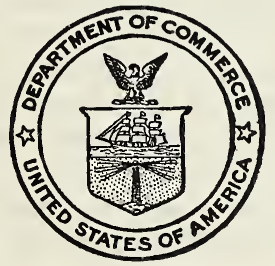

A RECORDED VOLUNTARY STANDARD

OF THE TRADE

UNITED STATES

GOVERNMENT PRINTING OFFICE

WASHINGTON : 1943 
PROMULGATION

of

COMMERCIAL STANDARD CS65-43

for

\section{METHODS OF ANALYSIS AND OF REPORTING FIBER COMPOSITION OF TEXTILE PRODUCTS}

(Second Edition)

On December 16, 1935, at the instance of the National Association of Wool Manufacturers, a general conference of representative manufacturers, distributors, and users of wool and part-wool fabrics adopted a recommended commercial standard for that commodity, which was subsequently accepted by the trade and promulgated as Commercial Standard CS65-38.

Because of the information required by the Wool Products Labeling Act of 1939, those parts of CS65-38 applying to the labeling of wool and part-wool fabrics as to fiber content were withdrawn beginning July 14, 1941, the effective date of the act.

On recommendation of the standing committee, a revision of the standard was submitted to the trade for acceptance on May 6, 1941. This revision includes a change in the name of the standard; includes methods of analysis and of reporting fiber composition; and broadens the scope to include all products containing cotton, rayon, silk, and woolen fibers. The revision has since been accepted by the trade for promulgation by the United States Department of Commerce, through the National Bureau of Standards.

The standard is effective as a basis for determining fiber composition and of reporting thereon from February 20, 1943.

Promulgation recommended.

I. J. Fairchild, Chief, Division of Trade Standards.

Promulgated.

Lyman J. Briggs,

Promulgation approved. Director, National Bureau of Standards.

Jesse H. Jones, Secretary of Commerce. 


\title{
METHODS OF
}

\section{ANALYSIS AND OF REPORTING FIBER COMPOSITION}

\author{
OF
}

\section{TEXTILE PRODUCTS}

\author{
(Second Edition) \\ COMMERCIAL STANDARD CS65-43
}

PURPOSE

1. The purpose of this standard is to provide standard methods for the quantitative analysis of finished products containing cotton, rayon, silk, or woolen fiber, and mixtures thereof, and of reporting on same, to eliminate confusion resulting from a diversity of methods of analysis and to protect the interests of the manufacturer, distributor, and user. These methods are not intended to show the individualpercentages of "wool," "reprocessed wool," or "reused wool" for purposes of the Wool Products Labeling Act of 1939.

\section{SCOPE}

2. This standard provides methods of analyzing finished products composed of cotton, rayon, silk, or woolen fiber, and mixtures of two or more of such fibers, and determining the percentage by weight of each kind of fiber present and the percentage by weight of total sizing, finishing, and other nonfibrous materials; provides methods of reporting on same; includes definitions of these fibers; and illustrates the manner by which testing laboratories may certify that the analyses have been conducted in accordance with the methods of the standard.

\section{DEFINITIONS}

3. Cotton.-The term "cotton" for the purpose of this standard is defined as the unicellular seed hair of the genus Gossypium.

4. Rayon.-The term "rayon" for the purpose of this standard is defined as the filaments made from various solutions of modified cellulose by pressing or drawing the cellulose solution through an orifice and solidifying it in the form of a filament.

4a. Acetate rayon.--Filaments and staple fiber composed of an acetic ester of cellulose which has been coagulated or solidified from its solution.

4b. Regenerated cellulose rayon.-Filaments and staple fiber composed of regenerated cellulose which has been coagulated or solidified 
from a solution of cellulose xanthate or nitrated cellulose, or from a solution of cellulose in ammoniacal copper oxide.

5. Silk.-The term "silk" for the purpose of this standard is defined as filaments and short fibers obtained from the cocoons of various types of silk worms, not including that known as tussah silk.

6. Woolen fiber. 1-The term "woolen fiber" for the purpose of this standard is defined as the fiber from the fleece of the sheep or lamb, angora goat, camel, alpaca, llama, cashmere goat, or vicuna.

7. Staple fiber.-The term "staple fiber" for the purpose of this standard is defined as fiber of spinnable length manufactured directly or by cutting continuous filaments.

8. The percentage of each fiber in a finished textile product, for the purpose of this standard, is based on the total oven-dry weight of the clean fibers and not on the oven-dry weight of the original specimen, which may contain sizing and finishing materials. ${ }^{2}$

\section{METHODS OF ANALYSIS}

Note.-The kinds of fibers in a product must be known before starting the analysis. Microscopic examination of fibers taken from the product and simple chemical tests will give this information. With it, the appropriate method of analysis can be selected. If fibers not listed in paragraphs 2 and 6 are present, due allowance must be made for them in reporting results.

9. Mechanical analysis.-If the different fibers occur separately in different yarns in the product, a specimen should be dissected. The specimen must be carefully selected to contain all the yarns of a complete pattern. The specimen from which the sizing, finishing, and nonfibrous materials are removed by the method in paragraph 10 shall be dried at $221^{\circ}$ to $230^{\circ} \mathrm{F}\left(105^{\circ}\right.$ to $\left.110^{\circ} \mathrm{C}\right)$ to constant weight and that weight recorded. The fibers are then separated, each kind dried separately at $221^{\circ}$ to $230^{\circ} \mathrm{F}\left(105^{\circ}\right.$ to $\left.110^{\circ} \mathrm{C}\right)$ to constant weight, and the percentage of each calculated and reported to the nearest whole number.

10. Method of analysis for total sizing, finishing, and other nonfibrous materials.-The purpose of this procedure is to remove all nonfibrous natural constituents of the fiber and added nonfibrous substances. Starch, china clay, soaps, some waxes, some nondrying oils, and the usual natural constituents are in this category and are removed by the procedure given. However, general directions for the removal of all possible substances which may be present cannot be given. The delustered rayons and some of the newer finishes present special problems. The analyst will have to meet special cases as they arise. When it is necessary to modify the procedure in order to remove completely nonfibrous constituents, the analyst shall make sure that purified samples of the fibers under consideration do not lose weight when subjected to the same treatment. Ordinarily, samples shall be analyzed in accordance with the following paragraphs.

10a. A specimen of approximately 5 grams shall be taken for test. Particular care shall be taken to prevent the loss of fibers in the treatments. The specimen shall be dried at $221^{\circ}$ to $230^{\circ} \mathrm{F}\left(105^{\circ}\right.$ to $\left.110^{\circ} \mathrm{C}\right)$

\footnotetext{
1 "Woolen fiber" as defined and used herein does not distinguish between the three classes of woolen fiber ("Wool," "reprocessed wool," and "reused wool") for purposes of the Wool Products Labeling Act of 1939 (Public No. 850-76th Congress).

${ }_{2}$ The percentage of sizing and finishing materials is based on the total oven-dry weight of the product.
} 
to constant weight. This gives the oven-dry weight of the original specimen, $B$ :

10b. The specimen shall then be extracted for 2 hours with carbon tetrachloride in a Soxhlet or similar extractor siphoning over a minimum of six times. The specimen shall be allowed to dry in the air. It shall then be washed by repeated immersion in hot distilled water, squeezing the specimen between each immersion.

10c. The specimen shall then be immersed in a 3-to 5-percent aqueous solution of a starch and protein-solubilizing enzyme preparation at $122^{\circ}$ to $140^{\circ} \mathrm{F}\left(50^{\circ}\right.$ to $60^{\circ} \mathrm{C}$ ) or the optimum temperature range for the particular enzyme used. It shall be squeezed while immersed, removed and squeezed again, and this procedure repeated at least three times. The purpose is to insure thorough wetting of the fibers by the enzyme solution. The enzyme solution shall then be maintained at $122^{\circ}$ to $140^{\circ} \mathrm{F}\left(50^{\circ}\right.$ to $\left.60^{\circ} \mathrm{C}\right)$, or the optimum temperature range for the particular enzyme used, and the specimen shall be kept immersed in it for 1 hour. A shorter time is permissible if sizing is removed in a shorter time. Fifteen minutes is sufficiont for some textiles. The specimen shall be immersed for two 30-minute periods in baths of boiling distilled water, rinsing it after each bath. Thorough rinsing is necessary in order to remove china clay from heavily filled fabrics. The rinsed specimen shall then be dried at $221^{\circ}$ to $230^{\circ} \mathrm{F}$ $\left(105^{\circ}\right.$ to $\left.110^{\circ} \mathrm{C}\right)$ to constant weight. This gives the oven-dry weight of clean fiber, $C$.

$10 \mathrm{~d}$. The percentage of sizing, finishing, and other nonfibrous materials (oven-dry basis) ${ }^{3}$ equals the oven-dry weight of the specimen, $B$, (paragraph 10a) minus the oven-dry weight of the clean fibers, $C$, (paragraph 10c) divided by the oven-dry weight of the specimen, $B$, and the quotient multiplied by 100 , i. e., $100(B-C) / B$.

10e. Reporting content of sizing, finishing, and other nonfibrous materials.-The sizing, finishing, and other nonfibrous materials shall be reported, in percent to the nearest whole number.

11. Method of analysis for mixtures of cotton and woolen fibers, rayon and woolen fibers, and silk and woolen fibers.

11a. A specimen of approximately 5 grams after removal of the sizing, finishing, and nonfibrous materials (paragraph 10) and drying to constant weight at $221^{\circ}$ to $230^{\circ} \mathrm{F}\left(105^{\circ}\right.$ to $\left.110^{\circ} \mathrm{C}\right)$ shall be accurately weighed, $C$. If the specimen is in the form of a fabric, a felt, or tightly twisted yarn, it is carefully unraveled and the tightly twisted yarns partly untwisted to facilitate the penetration of the yarns by the reagent used for the analysis. The specimen is then immersed for 7 to 10 minutes in a boiling 1-percent (by weight) solution of sulfuric acid (100 ml of solution per gram of fibers).

$11 \mathrm{~b}$. The specimen is then transferred to a Buchner funnel, Gooch crucible, or other suitable filter, and the excess acid solution removed by suction. The specimen is allowed to cool, and then placed in a $70 \pm 1$-percent sulfuric acid solution ${ }^{4}\left(100 \mathrm{ml}\right.$ per g of fibers) at $100^{\circ} \mathrm{F}$ $\left(37.8^{\circ} \mathrm{C}\right)$ and allowed to stand for 15 minutes, with frequent stirring. The liquid containing the insoluble fibers (woolen) is then poured through a Buchner funnel, Gooch crucible, or other suitable filter, using suction to draw the liquid through the filter. If the filtrate con-

\footnotetext{
3 See footnote 2 , page 2

$.4 \mathrm{~A} 70$-percent solution of sulfuric acid by weight, i. e., 70 grams of $\mathrm{H}_{2} \mathrm{SO}_{4}$ in $100 \mathrm{~g}$ of solution, is required. The acid should be titrated to determine its exact strength.
} 
tains fibers, it is again poured through the filter and the pad of fibers formed. When the filtrate is free of all fibers it is discarded. The pad of fibers is then washed with water, then with a 2-percent sodium bicarbonate solution, and finally with water until it is free of sulfates. The pad of fibers is then dried at $221^{\circ}$ to $230^{\circ} \mathrm{F}\left(105^{\circ}\right.$ to $\left.110^{\circ} \mathrm{C}\right)$ to constant weight. This is the oven-dry weight of the woolen fiber, $G$.

11c. The percentage of woolen fiber (oven-dry basis) equals the quotient obtained by dividing the oven-dry weight of the fibers, $G$ (paragraph $11 \mathrm{~b}$ ), by the weight of the oven-dry specimen free from sizing compounds, etc., $C$ (paragraph 11a), multiplied by 100, i. e., $100 \mathrm{G} / C$.

11d. Correction for reprocessed and reused wool.-Investigation has disclosed that when "reprocessed" or "reused wool," as defined in the Wool Products Labeling Act of 1939 is present to the extent of 100 percent, the amount of woolen fiber as determined in paragraph $11 \mathrm{c}$ may be lower than the actual amount of woolen fiber present by as much as 4 percent. Therefore, if reprocessed or reused wool is claimed or known to be present, then the percentage from paragraph 11c should be adjusted by adding to it an amount equal to the product of the sum of the percentages of reprocessed and reused wool claimed or known to be present times 0.04. For example, if it is claimed or known that a product contains 30 percent of reprocessed and reused wool and a woolen fiber content of 78.7 percent is obtained by the analysis given in paragraph 11, then there should be added to that percentage an amount equal to $30 \times 0.04$, or 1.2 percent, making the total 79.9 percent.

11e. The percentage of cotton, rayon, or silk (oven-dry basis) equals 100 minus the percentage of woolen fiber (paragraph 11c or 11d).

11f. Reporting fiber content in mixtures of cotton, rayon, or silk, and woolen fibers.-The fiber content in mixtures of cotton, rayon, or silk, and woolen fibers shall be reported separately, in percent, to the nearest whole numbers, for example: Cotton, rayon, or silk (delete two of these) .... percent; total woolen fiber (including "wool" "reprocessed wool," "reused wool," and/or specialty wool fibers) ... . percent.

12. Method of analysis for mixtures of cotton, rayon, silk, and woolen fibers.-A specimen of approximately $5 \mathrm{~g}$. after removal of the sizing, finishing, and nonfibrous materials (paragraph 10) and drying to constant weight at $221^{\circ}$ to $230^{\circ} \mathrm{F}\left(105^{\circ}\right.$ to $\left.110^{\circ} \mathrm{C}\right)$ shall be accurately weighed, $C$. Particular care shall be taken to prevent the loss of fibers in the analysis.

12a. Acetate rayon, acetone-soluble types. ${ }^{5}$ - The specimen referred to in paragraph 12 shall be agitated vigorously for 15 minutes in about 50 times its weight of acetone at room temperature. The solution shall be poured through a Buchner funnel, Gooch crucible, or other suitable filter, collecting the fiber residue in the form of a pad. The solution is poured through the pad until it is free of fibers. The residue shall be rinsed by alternate squeezing and immersion in acetone, two fresh portions of acetone being used. The residue shall be allowed to dry and then immersed in water at a temperature of about $158^{\circ} \mathrm{F}$ $\left(70^{\circ} \mathrm{C}\right)$. The excess water shall be removed by squeezing and the

${ }^{5} \mathrm{~A}$ few cellulose acetate rayons are not completely soluble in acetone. If the sample (by test) is one of these, then the glacial acetic acid method (paragraph 12b) should be used, otherwise the acetone method is preferable. 
residue dried at $221^{\circ}$ to $230^{\circ} \mathrm{F}\left(105^{\circ}\right.$ to $\left.110^{\circ} \mathrm{C}\right)$ to constant weight and the weight recorded, $D$.

12b. Acetate rayon, acetone-nonsoluble types.-When the specimen contains acetone-nonsoluble type of acetate rayon, it shall be treated as described in paragraph $12 \mathrm{a}$, except that glacial acetic acid shall be used instead of acetone, and the fibers shall not be permitted to dry before immersing them in water at $158^{\circ} \mathrm{F}\left(70^{\circ} \mathrm{C}\right)$ and washing until free of acetic acid. The specimen shall then be dried at $221^{\circ}$ to $230^{\circ}$ $\mathrm{F}\left(105^{\circ}\right.$ to $\left.110^{\circ} \mathrm{C}\right)$ to constant weight and the weight recorded, $D$.

12c. Silk. ${ }^{6}$ - The residue referred to in paragraph $12 \mathrm{a}$ or $12 \mathrm{~b}$ shall be cut to lengths of about 2 to $4 \mathrm{~mm}$ and agitated vigorously for 1 hour in $200 \mathrm{ml}$ of a clear aqueous solution of calcium thiocyanate of specific gravity 1.20 to 1.21 at $158^{\circ} \mathrm{F}$. $\left(70^{\circ} \mathrm{C}\right.$.), made just acid to litmus with acetic acid, and maintained at a temperature of $158^{\circ}$ $\pm 4^{\circ} \mathrm{F}\left(70^{\circ} \pm 2.2^{\circ} \mathrm{C}\right)$. Precautions shall be taken to prevent evaporation from the solution with consequent concentration of the thiocyanate. The fibers which are not dissolved shall be collected in a small Buchner funnel, Gooch crucible, or other suitable filter, preferably with the aid of suction. When a good pad of fibers has formed on the filter, the hot liquid shall be poured through a second time to collect all fibers on the pad. The fibers shall then be agitated for 5 minutes in a fresh $200-\mathrm{ml}$ portion of the thiocyanate solution. The filtration shall be repeated and the fibers washed with hot distilled water until free from thiocyanate. The residue shall be dried at $221^{\circ}$ to $230^{\circ} \mathrm{F}\left(105^{\circ}\right.$ to $\left.110^{\circ} \mathrm{C}\right)$ to constant weight and the weight recorded, $E$.

12d. Regenerated cellulose rayon.-The residue referred to in paragraph 12c shall be treated in accordance with the procedure in paragraph 12c, except that the acid solution of calcium thiocyanate shall be of a specific gravity 1.35 to 1.36 at a temperature of $158^{\circ} \mathrm{F}\left(70^{\circ} \mathrm{C}\right)$. The weight of the dried residue from this treatment is designated $F$.

12e. Cotton and woolen fibers.-The residue referred to in paragraph $12 \mathrm{~d}$ shall be treated in accordance with the method outlined in paragraph 11. The weight of the dry residue is designated $G$.

12f. Calculations.

$$
\begin{aligned}
& \text { Acetate rayon .................. }=\frac{C-D}{C} \times 100 \text { percent, } \\
& \text { Silk. . . . . . . }=\frac{D-E}{C} \times 100 \text { percent, } \\
& \text { Regenerated cellulose rayon........ }=\frac{E-F}{C} \times 100 \text { percent, } \\
& \text { Cotton ....................... }=\frac{F-G}{C} \times 100 \text { percent, } \\
& \text { Woolen fiber . . . . . . . . . . }=\frac{G}{C} \times 100 \text { percent, }
\end{aligned}
$$

where

$C=$ the oven-dry weight of the specimen after removal of nonfibrous materials (paragraph 12),

$D=$ the oven-dry weight of the specimen after removal of

6 When tussah silk is not present. If tussah silk is present, the analyst should use the most accurate method of analysis available to him at that time. 
nonfibrous materials and acetate rayon (paragraph $12 \mathrm{a}$ or $12 b)$,

$E=$ the oven-dry weight of the specimen after removal of nonfibrous materials, acetate rayon, and silk (paragraph 12c),

$F=$ the oven-dry weight of the specimen after removal of nonfibrous materials, acetate rayon, silk, and regenerated cellulose rayon (paragraph $12 \mathrm{~d}$ ), and

$G=$ the oven-dry weight of the specimen after removal of nonfibrous materials, acetate rayon, silk, regenerated cellulose rayon, and cotton (paragraph 12e).

12g. Correction for reprocessed and reused wool.--Investigation has disclosed that when "reprocessed" or "reused wool" as defined in the Wool Products Labeling Act of 1939 is present to the extent of 100 percent, the amount of woolen fiber as determined in paragraph $12 \mathrm{f}$ may be lower than the actual amount of woolen fiber present by as much as 4 percent. Therefore, if reprocessed or reused wool is claimed or known to be present, then the percentage from paragraph $12 \mathrm{f}$ should be adjusted by adding to it an amount equal to the product of the sum of the percentages of reprocessed and reused wool claimed or known to be present times 0.04 and subtracting an equal amount from the percentages of cotton in paragraph 12f. For example, if it is claimed or known that a product contains 30 percent of reprocessed and reused wool and a woolen fiber content of 58.7 percent and a cotton content of 18.3 percent are obtained by the analysis given in paragraph 11, then there should be added to the woolen fiber percentage and subtracted from the cotton percentage an amount equal to $30 \times 0.04$, or 1.2 percent, making these totals 59.9 and 17.1 percent, respectively.

12h. Reporting fiber content in mixtures of cotton, rayon, silk, and woolen fibers.- The fiber content in mixtures of cotton, rayon, silk, and woolen fibers shall be reported separately, in percent, to the nearest whole numbers, for example: Cotton ...- percent; rayon _... percent; silk _... percent; total woolen fiber (including "wool", "reprocessed wool", "reused wool", and/or specialty wool fibers) _. . . percent.

\section{CERTIFICATION BY LABORATORIES ${ }^{7}$}

13. The following illustrates the manner in which a laboratory may certify compliance with the commercial standard. Laboratories complying with the methods of testing and reporting as recorded in the standard may indicate that fact by the following statement on their reports. Laboratory reports shall not be used in any manner to mislead the purchaser.

The warrants that the figures for fiber content were obtained and reported in accordance with Commercial Standard CS65-43, as issued by the National Bureau of Standards.

\section{NOTES}

14. The methods of test included under paragraphs 10,11 , and 12 conform in all essential requirements with the respective methods of

${ }_{7}$ Compliance with this standard does not relieve the seller from compliance with the Wool Products Labeling Act of 1939 (Public No. 850-76th Congress). 
the American Society for Testing Materials Tentative Methods of the Quantitative Analysis of Textiles, ASTM Designation: D 629-42 T.

15. The methods included under paragraphs 10,11, and 12 (not including 12c) conform in all essential requirements with Methods of Fiber Identification and Quantitative Separation as given in the 1942 Year Book of the American Association of Textile Chemists \& Colorists.

\section{EFFECTIVE DATE}

The standard is effective as a basis for analyzing and reporting from February 20, 1943.

\section{STANDING COIMIITEE}

The following individuals comprise the membership of the standing committee, which is to review, prior to circulation for acceptance, revisions proposed to keep the standard abreast of progress. Each organization nominated its own representatives. Comment concerning the standard and suggestions for revision may be addressed to any member of the committee or to the Division of Trade Standards, National Bureau of Standards, which acts as secretary for the committee.

Hugh Christison (chairman), Arlington Mills, Lawrence, Mass. Representing National Association of Wool Manufacturers.

Eunice F. Barnard, National Council of Women, c/o Alfred P. Sloan Foundation, Inc., 30 Rockefeller Plaza, New York, N. Y.

Morton J.' Baum, Hickey-Freeman Co., 1155 Clinton Avenue, N., Rochester, N. Y. Representing Clothing Manufacturers Association of the United States of America.

C. M. Blackhall, Pacific Mills, 261 Fifth Avenue, New York, N. Y. Representing National Association of Wool Manufacturers.

J. M. Burke, Carter Dry Goods Co., Louisville, Ky. Representing Wholesale Dry Goods Institute.

Ephraim Freedman, R. H. Macy \& Co., Inc., 34th \& Broadway, New York, N. Y. Representing National Retail Dry Goods Association.

V. W. Gottschling, Hayward-Schuster Co., Inc., 51 Madison Avenue, New York, N. Y. Representing National Association of Wool Manufacturers.

Gerald D. Grosner, 1325 F Street, Washington, D. C. Representing the National Association of Retail Clothiers and Furnishers.

A. J. Kellner, United States Testing Co., 1415 Park Avenue, Hoboken, N. J. Representating also the American Council of Commercial Laboratories.

Mortimer Lanzit, National Dress Manufacturers Association, 1450 Broadway, New York, N. Y.

HARRY LEVINE, Textile Testing \& Research Laboratories, 24 W. 26th Street. New York, N. Y. Representing American Association of Textile Technologists,

Pauline BeEry MAcK, The Pennsylvania State College, State College, Pa. Representing the American Home Economics Association.

LaUra E. Pratt, Sears, Roebuck \& Co., Chicago, Ill. Representing Mail Order Association of America.

F. A. Prisley, Hayward-Schuster Woolen Mills, E. Douglas, Mass. Representing Committee D-13, American Society for Testing Materials.

Bertil A. Ryberg, Lowell Textile Institute, Lowell, Mass. Representing American Association of Textile Chemists \& Colorists.

Frank Sturt, Better Fabrics Testing Bureau, Inc., 101 West 31st Street, New York, N. Y.

K. B. Willson, National Better Business Bureau, Inc., Chrysler Building, New York, N. Y.

Herber' A. EHRMan (secretary), Division of Trade Standards, National Bureau of Standards, Washington, D. C. 


\section{HISTORY OF PROJEC'T}

The Board of Directors of the National Association of Wool Manufacturers adopted on February 5, 1935, "Regulations for the Labeling of Wool and Part-Wool Knitted or Woren Fabrics." Desirous of having these regulations effective on a national basis, that Association, under date of October 3, 1935, requested the cooperation of the National Bureau of Standards in the establishment of a commercial standard based on these regulations to cover the labeling or otherwise describing the wool-fiber content of wool and part-wool fabrics.

At a general conference in New York on December 16, 1935, the proposed standard was adopted with some changes to meet the composite recommendation of the wool growers, the manufacturers, distributors, and users of wool and part-wool fabrics. The draft was circulated to those concerned on January 15, 1936, for written acceptance.

Subsequent study revealed a ruling of the United States Supreme Court that the word "wool" when used as an adjective means "made of wool" (Winsted Hosiery Case, 258 U. S. 483). Accordingly, some modifications in the text were drafted for compatibility with the ruling and to strengthen the enforcibility of the standard through the Federal Trade Commission and the courts.

The modified recommended standord was submitted to acceptors of record on September 14, 1936, and to all others interested on September 25, 1936. The standard, known as Wool and Part-Wool Fabrics, Commercial Standard C $\$ 65-38$, became effective on January $1,1938$.

The labeling required by the Wool Products Labeling Act of 1939 being different from that of the commercial standard, a letter was circulated on July 11, 1941, with the approval of the standing committee to those concerned, to the effect that the parts of the commercial standard applying to the labeling of wool and part-wool fabrics as to fiber content should be considered withdrawn beginning July 14 , 1941, the effective date of the act.

\section{FIRST REVISION}

At the request of certain distributors and laboratories, and on the recommendation of the standing committee, a revision of the standard was drafted covering only methods of analysis and of reporting fiber composition, and broadening the scope to include the quantitative determination of rayon, cotton, and silk. That draft was circulated to all concerned for acceptance on May 6, 1941.

In line with comment received and conferences with officials of the Federal Trade Commission, additions were made to the draft of May 6,1941 , in order to eliminate any chance of the use of this standard in any way that would be in conflict with the requirements of the act. Revised drafts were circulated to acceptors of record on July 30 and September 15, 1942, to nonacceptor producers on July 31 and September 14, 1942, and to nonacceptor commercial textile testing laboratories on September 16, 1942. Announcement of the effective date of the revision was issued on January 20, 1943. 


\section{ACCEPTANCE OF COMMERCIAL STANDARD}

If acceptance has not previously been filed, this sheet properly filled in, signed, and returned will provide for the recording of your organization as an acceptor of this commercial standard.

Division of Trade Standards,

Date

National Bureau of Standards,

Washington, D. C.

\section{Gentlemen:}

Having considered the statements on the reverse side of this sheet, we accept the Commercial Standard CS65-43 as our standard of practice for testing and reporting the fiber content of textile products, with which we are directly conceined as a

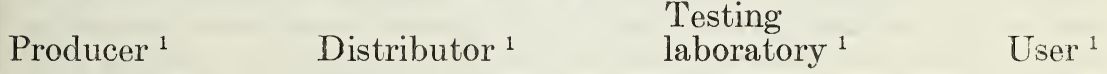

We will assist in securing its general recognition and use, and will cooperate with the standing committee to effect revisions of the standard when necessary.

Signature of individual officer

(Kindly typewrite or print the following lines)

Name and title of above officer

Organization

(Fill in exactly as it should be listed)

Street address

City and State

1 Please designate which group you represent by drawing lines through the other three. Please file separate acceptances for all subsidiary companies and affiliates which should be listed separately as acceptors. In the case of related interests, trade papers, colleges, etc., desiring to record their general approval, the words "In Principle" should be added after the signature. 


\section{TO THE ACCEPTOR}

The following statements answer the usual questions arising in connection with the acceptance and its significance:

1. Enforcement.-Commercial standards are commodity specifications voluntarily established by mutual consent of those concerned. They present a common basis of understanding between the producer, distributor, and consumer and should not be confused with any plan of governmental regulation or control. The United States Department of Commerce has no regulatory power in the enforcement of their provisions, but since they represent the will of the interested groups as a whole, their provisions through usage soon become established as trade customs, and are made effective through incorporation into sales contracts by means of labels, invoices, and the like.

2. The acceptor's responsibility.-The purpose of commercial standards is to establish for specific commodities, nationally recognized grades or consumer criteria and the benefits therefrom will be measurable in direct proportion to their general recognition and actual use. Instances will occur when it may be necessary to deviate from the standard, and the signing of an acceptance does not preclude such departures; however, such signature indicates an intention to follow the commercial standard where practicable, in the production, distribution, or consumption of the article in question.

3. The Department's responsibility.-The major function performed by the Department of Commerce in the voluntary establishment of commercial standards on a Nation-wide basis is fourfold: first, to act as an unbiased coordinator to bring all interested parties together for the mutually satisfactory adjustment of trade standards; second, to supply such assistance and advice as past experience with similar programs may suggest; third, to canvass and record the extent of acceptance and adherence to the standard on the part of producers, distributors, and users; and fourth, after acceptance, to publish and promulgate the standard for the information and guidance of buyers and sellers of the commodity.

4. Announcement and promulgation.-When the standard has been endorsed by a satisfactory majority of production or consumption in the absence of active, valid opposition, the success of the project is announced. If, however, in the opinion of the standing committee or the Department of Commerce, the support of any standard is inadequate, the right is reserved to withhold promulgation and publication. 


\section{ACCEPTORS}

The organizations and individuals listed below have accepted this specification as their standard of practice in analyzing and reporting the fiber composition of textile products. Such endorsement does not signify that they may not find it necessary to deviate from the standard, nor does it signify that the testing laboratories so listed guarantee all of their test reports to conform with the requirements of this standard. Therefore specific evidence of conformity should be obtained where required.

\section{ASSOCIATIONS}

American Association of Textile Chemists \& Colorists, Lowell, Mass. (In principle.)

American Association of Textile Technologists, New York, N. Y.

American Council of Commercial Laboratories, Hoboken, N. J.

American Institute of Laundering, JoJiet, Ill.

Girl Scouts, Inc., New York, N. Y.

Good Housekeeping Institute, New York, N. Y.

Mail Order Association of America, Chicago, Ill. (In principle.)

National Association of Hosiery Manufacturers, New York, N. Y.

National Association of Negro Tailors, Designers, Dressmakers \& Dry Cleaners, Inc., Burlington, N. C.

National Council of Women, New York, N. Y. (In principle.)

National Retail Dry Goods Association, New York, N. Y. (In principle.)

\section{FIRMS}

Abbot Worsted Co., Graniteville, Mass. Abbott Co., Amos, Dexter, Maine.

Abbott Worsted Mills, Wilton, N. H.

Abercrombie \& Fitch Co., New York, N. Y.

Adam, Meldrum \& Anderson Co., Buffalo, N. Y.

Agawam Woolen Co., Inc., Agawam, Mass.

American Analytical Laboratories, Inc., New York, N. Y.

American Cyanamid Co., Cales Chemical Div., Bound Brook, N. J.

American Felt Co., Glenville, Conn.

American Seating Co., Grand Rapids, Mich.

American Textile Woolen Co., Sweetwater, Tenn.

American Thread Co., The, New York, N. Y.

American Wool Handbook Co., New York, N. Y. (In principle.)

American Woolen Co., New York, N. Y.

Ames Worsted Co., Lowell, Mass., and Southbridge, Mass.
Anglo Fabrics, Inc., Oxford, Mass.

Ardsley Textile Sales Co., New York, N. Y.

Arlington Mills, Boston, Mass.

Artloom Corporation, Philadelphia, Pa.

Astoria Weaving Corporation, Long Island City, N. Y.

Athens Woolen Mill, Athens, Tenn.

Atlanta Woolen Mills, Atlanta, Ga.

Atlas Underwear Co., The, Piqua, Ohio.

Ayres Co., L. S., Indianapolis, Ind.

B-B Stores, Inc., Logansport, Ind.

Badger Worsted Mills, Grafton, Wis.

Ball Stores, Inc., Muncie, Ind.

Bamberger-Reinthal Co., The, Cleveland, Ohio.

Barbour Mills (Fabric Division of Barbour Welting Co.), Brockton, Mass.

Barnett Woolen Mills, Milwaukee, Wis.

Belgian Spinning Co., Waltham, Mass.

Belleville Woolen Co., Allenton, R. I.

Belltex Mills, Philadelphia, Pa.

Belmont Woolen Yarn Mills, Woonsocket, R. I.

Bemidji Woolen Mills, Bemidji, Minn.

Bennington Yarns, Inc., Bennington, Vt.

Berg, Inc., Charles F., Portland, Oreg.

Berkeley Woolen Co., Martinsburg, W. Va.

Berkshire Woolen Co., Pittsfield, Mass.

Better Fabrics Testing Bureau, New York, N. Y.

Birdsall Brothers Co., Seelyville, Pa.

Blackstone Plush Mills, Inc., Clinton, Mass. (In principle.)

Bloomingdale Brothers, Inc., New York, N. Y.

Blum Store, The, Philadelphia, Pa.

Bolger Brothers, Philadelphia, Pa.

Bon Marche, The, Seattle, Wash.

Botany Worsted Mills, Passaic, N. J.

Bowser Morner Testing Laboratories, Dayton, Ohio.

Bradley \& Co., W. W., Delavan, Wis.

Broad Brook Co., Broad Brook, Conn.

Broadalbin Knitting Co., Ltd., The, Broadalbin, N. Y.

Broadway Department Store, Inc., Los Angeles, Calif.

Broeman \& Co., F. C., Cincinnati, Ohio. 
Brownsville Woolen Mi'ls, Browns: ville, Oreg.

Brumbach, Inc., A. J., Esterly, Pa.

Brunswick Worsted Mills, Inc., Moosup, Conn.

Bry Block Mercantile Corporation, Memphis, Tenn.

Buckley \& Cohen, Inc., New York, N. Y.

Buckley \& Mann, Inc., Franklin, Mass.

Bulkley, Weinberg \& Tormey, Inc., New York, N. Y.

Burke \& Co., Inc., J. Franklin, New York, N. Y.

Bush Woolen Mills Co., Inc., The, Dresden, Ohio.

California, University of, Berkeley, Calif. (In principle.)

Caron Spinning Co., Rochelle, Ill.

Carson Pirie Scott \& Co., Chicago, Ill.

Cascade Woolen Mill, Oakland, Maine.

Caswell, Inc., C. A., Bloomsburg, Pa.

Charlottesville Woolen Mills, Charlottesville, Va.

Charlton Woolen Co., Charlton City, Mass.

Chatham Manufacturing Co., Elkin, N. C.

Cherry Brook Worsted Co., Woonsocket, R. I.

Cheshire Mills, Harrisville, N. H.

Children's Shop (Miss Cannon's Shop), Cambridge, Mass.

Chippəwa Falls Woolen Mill Co., Chippewa Falls, Wis.

Clanp Co., Inc., Charles E., Braintree, Mass.

Clear Spring Worsted Mills, Inc., Doylestown, $\mathrm{Pa}$.

Cleveland Worsted Mills Co., The, Cleveland, Ohio.

Clinton Woolen Manufacturing Co., Clinton, Mich.

Cohen, Goldman \& Co., Inc., New York, N. Y.

Collins \& Aikman Corporation, New York, N. Y.

Colonial Weavers, Inc., Wilkinsonville, Mass. (In principle.)

Colonial Woolen Mills Co., The, Cleveland, Ohio.

Colorado Knitting Mills, Denver, Colo.

Columbiaville Woolen Mill, Columbiaville, Mich.

Comins \& Co., Inc., Rochdale, Mass.

Conrad \& Co., Inc., Boston, Mass.

Consumers Testing Laboratories, Phliadelphia, $\mathrm{Pa}$.

Continental Mills, Inc., Philadelphia,

Panwell \& Co., E. L., Philadelphia, Pa.

Coronet Knitting Mills, New York, N. Y.

Cox \& Fuller, New York, N. Y.

Cresbury Clothes, Inc., Buffalo, N. Y.

Crescent Woolen Mills Co., Two Rivers, Wis.

Crown Mills, Inc., Marcellus, N. Y.

Crown Worsted Mills, Inc., Providence, R. I.

Crystal, Inc., David, New York, N. Y. Cumberland Gap Woolen Mills, Harriman, Tenn.

Cumberland Worsted Mills, Woonsocket, R. I.

Curvon Corporation, The, New York, N. Y.

Custom Woolen Mill (J. B. Courtney \& Co.), Appleton, Wis.

D. \& M. Woolen Mills, Putnam, Conn.

Dallas Laboratories, Dallas, Tex.

Dalton Co., The, Baton Rouge, La.

Davidson Woolen Mills, Inc., John B., Eaton Rapids, Mich.

Derby Co., The, Lawrence, Mass.

Detroit Testing Laboratory, The, Detroit, Mich. (In principle.)

Dickey \& Sons, Inc., W. J., Oella, Md.

Doerflinger Co., The Wm., La Crosse, Wis.

Dole \& Co., E., Campton, N. H.

Dominion Textile Co., Ltd., Montreal, Que., Canada.

Doran \& Kurriss, Waltham, Mass. (In principle.)

Dorset Woolen Co., Slocum, R. I.

Dumbarton Woolen Mills, Dexter, Maine.

Dunderry Woolen Mills, Rockford, Ill.

Dunn Worsted Co., J. F., Providence, R. I.

Eavenson \& Levering Co., Camden, N. J. (In principle.)

Effron's, Inc., Chattanooga, Tenn.

Ekroth Laboratories, Inc., Brooklyn, N. Y.

Elder Manufacturing Co., St. Louis, Mo.

Elliott Manufacturing Co., Manchester, N. H.

Energetic Worsted Corporation, Bridgeport, $\mathrm{Pa}$.

Englehart Woolen Mill Co., Albright, W. Va.

Esmond Mills, Inc., The, Esmond, R. I.

Esselen, Inc., Gustavus J., Boston, Mass.

Esterly Woolen Co., Esterly, Pa.

Evenknit Hosiery Mills, Bay City, Mich.

Fair, The, Chicago, Ill.

Faith Mills, Inc., Averill Park, N. Y.

Falls Yarn Mills, Woonsocket, R. I.

Fandel Co., St. Cloud, Minn.

Faribault Woolen Mill Co., Faribault, Minn.

Field Co., The L. H., Jackson, Mich.

Field \& Co., Marshall, Manufacturing Division, Spray, N. C.

Fine Brothers-Matison Co., Laurel, Miss.

Fine's Dress Goods Shop, Attleboro, Mass. 
Fisher Sons \& Co., Inc., M., New York, N. Y.

Fonda Glove Lining Co., Fonda, N. Y. Fort Schuyler Knitting Co., Utica, N. Y. Fowler's, Inc., Glens Falls, N. Y.

Frankford Worsted Mills, Inc., Philadelphia, $\mathrm{Pa}$.

Franklinshire Worsted Mills, Philadelphia, $\mathrm{Pa}$.

Frederic Woolen Mill, Frederic, Wis.

French Worsted Co., The, Woonsocket, R. I.

Freneau \& Co., Inc., E. S., New York, N. Y.

Fries \& Schuele Co., Cleveland, Ohio.

Frisch Knitting Mills Co., H. E., Cleveland, Ohio. (In principle.)

Froehling \& Robertson, Inc., Richmond, Va.

Gable Co., The William F., Altoona, Pa.

Gallin Knitting Mills, Cleveland, Ohio.

Gardiner Warring Co., Florence, Ala.

Gardner Co., J. T., Philadelphia, Pa.

Garon's Knitting Mills, Duluth, Minn.

Gaunt Worsted Mills, Centreville, R. I.

Gay Brothers Co., Cavendish, Vt.

General Dyestuff Corporation, New York, N. Y.

General Testing Laboratories, Inc., Detroit, Mich.

Gertz, Inc., B., Jamaica, N. Y.

Gilbert Knitting Co., Inc., Little Falls, N. Y.

Glen Woolen Mills, Inc., Norwich, Conn.

Glenside Mills Corporation, Skaneateles Falls, N. Y.

Globe Knitting Works, Grand Rapids, Mich.

Glover Co., H. B., Dubuque, Iowa.

Gold Mark Knitting Co., Woonsocket, R. I.

Goldberg's Corporation, Trenton, N. J.

Goodall Worsted Co., Sanford, Maine.

Grant Co., W. T., New York, N. Y.

Greenfield Co., M. E., New York, N. Y.'

Grosner of Washington, Washington, D. C.

Guerin Mills, Inc., Woonsocket, R. I.

Haft \& Sons, Morris, New York, N. Y.

Halle Bros. Co., The, Cleveland, Ohio.

Hampshire Worsted Mills, Manchester, N. H.

Hampton Looms of Virginia, Inc., Bedford, Va.

Hart Schaffner \& Marx, Chicago, Ill.

Hartford Woolen Co., Inc., Hartford, Vt.

Hatch Textile Research, New York, N. Y.

Hayward-Schuster Co., Inc., New York, N. Y.

Hayward-Schuster Woolen Mills, Inc., East Douglas, Mass.

Hickey-Freeman Co., Rochester, N. Y.

Hind \& Harrison Plush Co., The, Clark Mills, N. Y. (In principle.)
Holliday, Norris L., Philadelphia, Pa.

Hollins \& Co., Inc., William, Forestdale, R. I.

Hopeville Manufacturing Co., Inc., Worcester, Mass. (In principle.)

Horne Co., Joseph, Pittsburgh, Pa.

Horner Woolen Mills Co., Eaton Rapids, Mich.

Hospital Bureau of Standards \& Supplies, Inc., New York, N. Y.

House \& Sons, Inc., Chas. W., Unionville, Conn.

Houston, Better Business Bureau of, Houston, Tex. (In principle.)

Hudson Worsted Co., Hudson, Mass. (In principle.)

Hughes Woolen Mill, Camden, Maine.

Huguet Fabrics Corporation, New York, N. Y.

Humboldt Bay Woolen Co., Eureka, Calif.

Hunt Co., Robert W., Chicago, Ill.

Huntington Textile Co., Inc., Huntington, Mass.

Huyck \& Sons, F. C. (Kenwood Mills), Rensselaer, N. Y.

Indera Mills Co., Winston-Salem, N. C. Industrial By-Products \& Research Corporation, Philadelphia, Pa.

Irving \& Son, Inc., James, Chester, Pa.

Jagger Brothers, Inc., Sanford, Maine.

Jefferson Woolen Mills, Knoxville, Tenn.

Jewell Brook Woolen Co., Ludlow, Vt.

Johnson Woolen Co., Cyril, Stafford Springs, Conn.

Jones Knitting Mills, Los Angeles, Calif.

Kalamazoo Pant Co. (Successor to Sam Rosenbaum \& Sons Co.), Kalamazoo, Mich.

Kaufman Store, Inc., The, Richmond, Va.

Kaufmann Department Stores, Inc., Pittsburgh, Pa.

Kay Woolen Mill Co., Thos., Salem, Oreg.

Keller's Department Store, Liberty, N. Y.

Kent Manufacturing Co., The, Clifton Heights, Delaware Co., Pa.

Kezar Falls Woolen Co., Kezar Falls, Maine.

Kilpatrick \& Co., Thomas, Omaha, Nebr.

Kinkel, John, Union City, N. J. principle.)

Klous Co., Inc., Henry, Lawrence, Mass.

Knitcraft Manufacturing Co., San Francisco, Calif.

Kommel \& Sons, A., New York, N. Y.

Kosack Co., A., New York, N. Y.

Lafayette Worsted Spinning Co., Woonsocket, R. I.

Lansburgh \& Brother, Washington, D. C. 
LaWall \& Harrisson, Philadelphia, Pa. Lawrence Manufacturing Co., Lowell, Mass.

Lawrence Woolen Co., Lawrence, Mass.

Lazarus \& Co., F. \& R. (Bureau of Standards), Columbus, Ohio.

Leaksville Woolen Mills, Inc., The, Charlotte, N. C.

Lebanon Knitting Mill, Inc., Pawtucket, R. I.

Lebanon Woolen Mills, Lebanon, Tenn.

Lebanon Woolen Mills Corporation, Lebanon, N. H.

Leedom Co., Thomas L., Bristol, Pa.

Leeds College of Technology, Leeds, Yorkshire, England. (In principle.)

Lees \& Sons Co., James, Bridgeport, Pa.

Leinbach Co., Inc., The J. G., Reading, $\mathrm{Pa}$.

Leonard \& Co., F. S., Lake Placid, N. Y.

Leonard \& Co., W. C., Saranac Lake, N. Y.

Leveen \& Co., William, New York, N. Y.

Levi \& Rottenberg, Inc., New York, N. Y.

Levin \& Sons Co., The Simon, Baltimore, Md.

Levys, Owensboro, Ky.

Lexington Worsted Mills, Inc., Central Falls, R. I.

Libbey Co., W. S., Lewiston, Maine.

Limerick Yarn Mills, Limerick, Maine.

Lincoln Worsted Co., Philadelphia, Pa.

Lincolnsfield Mills, Lincoln, Maine.

Lippitt Woolen Co., Woonsocket, R. I.

Lister Worsted Co., Inc., The, Stillwater, R. I.

Litchfield Woolen Mills Co., Litchfield, Minn.

Livingston Worsted Mills, Inc., Holyoke, Mass.

Lonsdale Fabrics, Philadelphia, $\mathrm{Pa}$.

Lorraine Manufacturing Co., Pawtucket, R. I.

Los Angeles Testing Laboratory, Los Angeles, Calif.

Lowenthal \& Sons, Max, Rochester, N. Y.

Lucas Woolen Mill, Jefferson, Wis.

Luckey, Platt \& Co., Poughkeepsie, N. Y'.

Lymansville Co., North Providence, R. I.

Maas Chemical Co., A. R., South Gate, Calif. (In principle.)

Mackie Worsted Mills, Inc., Allendale, R. I.

Macy \& Co., Inc., R. H., New York, N. Y.

Majestic Fabrics Corporation, Boston, Mass.

Malden Mills, Malden, Mass.

Manchester Worsted Mills, Methuen, Mass. (In principle.)

Mann \& Co., W. D., Franklin, Mass.

Mansmann Co., Albert J., Pittsburgh, $\mathrm{Pa}$.
Marshall Spinning Corporation of Rhode Island, Walter, Johnston, R. I.

Marsh's, Hudson, N. Y.

Massachusetts Mohair Plush Co., Lowell, Mass.

Masurel Worsted Mills, Inc., Woonsocket, R. I.

Maxon \& Co., G. W., Berlin, N. Y.

May Co., The, Los Angeles, Calif.

Mayflower Worsted Co., Kingston, Mass.

McAteer, H. J., New York, N. Y.

McEvoy, Inc., John F., New York, N. Y.

Methuen International Mills, Methuen, Mass. (In principle.)

Meyer Woolens, Inc., New York, N. Y. Meyers-Arnold, Greenville, S. C.

Millard Yarn Co., Ballston Spa, N. Y. Miller \& Paine, Lincoln, Nebr.

Miner Laboratories, Chicago, Ill.

Minnesota Knitting Mills, St. Paul, Minn.

Minnesota, University of, Division of Home Economics, St. Paul, Minn. (In principle.)

Mitchell \& Son, Allen R. (Shackamaxon Mills), Philadelphia, Pa.

Monomac Spinning Co., Lawrence, Mass.

Montgomery Ward \& Co., Chicago, Ill.

Moore Co., Harry C., Nevada, Mo.

Morgan Memorial Cooperative Industries \& Stores, Inc., Boston, Mass.

Morse Shoe Stores, Boston, Mass. (In principle.)

Munger \& Co., Inc., H. G., Herkimer, N. Y.

Myrtle Knitting Mills, Inc., Unionville, Conn.

Nachman's Department Store, Inc., Newport News, Va.

Nashua Manufacturing Co., Nashua, N. H

National Better Business Bureau, Inc., New York, N. Y.

National Department Stores Management \& Buying Corporation, New York, N. Y.

National Worsted Mills, Inc., Jamestown, N. Y.

Neumann-Endler, Inc., Danbury, Conn.

New Bedford Textile School, New Bedford, Mass.

New England Fibre Blanket Co., Worcester, Mass.

New Orleans, Inc., Better Business Bureau of, New Orleans, La. (In principle.)

New York Testing Laboratories, Inc., New York, N. Y.

Nichols \& Co., Inc., Boston, Mass. (In principle.)

Nixon Specialty Co., Indian Orchard, Mass.

North American Knitting Co., Mansfield, Ohio. 
North Star Woolen Mill Co., Minneap- Prairie du Chien Woolen Mill Co., olis, Minn.

Northfield Mills, Inc., Northfield, Vt.

Novelty Knitting Mills, Inc., Philadelphia, $\mathrm{Pa}$.

Oak Worsted Mills, Philadelphia, Pa.

Oakes \& Co., Inc., Thomas, Bloomfield, N. J.

Oaklane Sportwear (David Freeman \& Son), Chicago, Ill.

Octonek Knitting Co., Seattle, Wash.

Oneita Knitting Mills, Utica, N. Y.

Oppenheimer-Franken, Inc., A. \& S., New York, N. Y.

Oregon Worsted Co., Inc., Astoria, L. I., N. Y.

Original Utah Woolen Mills, Salt Lake City, Utah.

Orr Felt \& Blanket Co., The, Piqua, Ohio.

Orthmann Laboratories, Inc., The, Milwaukee, Wis.

Osborne Laboratories, Raymond, Los Angeles, Calif.

Oxford Looms, Inc., Oxford, Mass.

Pacific Mills, Worsted Division, Lawrence, Mass.

Packard \& Co., Inc., L. W., Ashland, N. H.

Paris Woolen Mills, Stayton, Oreg.

Park Manufacturing Co., George, Dexter, Maine.

Park \& Sons, Inc., William, Stafford, Conn.

Park Woolen Co., Inc., The Angus, Hanover, Conn.

Parke Snow, Inc., Waltham, Mass.

Parsons Souders Co., The, Clarksburg, W. Va.

Patzig Testing Laboratories, Des Moines, Iowa.

Pearce Manufacturing Co., Latrobe, Pa.

Penn Worsted Co., Philadelphia, Pa.

Penney Co., Inc., J. C., New York, N. Y.

Penniman \& Browne, Baltimore, Md.

Pennsylvania Hospital, Philadelphia, Pa.

Pennsylvania State College, The, State College, Pa.

Peoples Store, The, Bend, Oreg.

Philadelphia Laboratory, Philadelphia, Pa.

Philadelphia Worsted Mills, Philadelphia, Pa.

Phillips-Lester Man u f a c t uring Co., Birmingham, Ala.

Philmont Yarn Co., Philmont, N. Y.

Pittsburgh Testing Laboratory, Pittsburgh, Pa.

Portage Hosiery Co., Portage, Wis.

Portland Woolen Mills, Inc., Portland, Oreg.

Potlatch Mercantile Co., Potlatch, Idaho.

Powers Manufacturing Co., The, Waterloo, Iowa.

Prairie du Chien, Wis.

Premier Worsted Mills, Boston, Mass.

Princeton Knitting Mills, Inc., Watertown, Conn.

Prospect Knitting Mills, Inc., Boston, Mass.

Pullar, Robert Taft, New York, N. Y.

Ransohoffs, Inc., San Francisco, Calif. (In principle.)

Raylaine Worsteds, Inc., Manchester, N. H.

Rike Kumler Co., The, Dayton, Ohio. Ring \& Co., Jonathan, Philadelphia, Pa.

Rittenberg Brothers, New York, N. Y.

Riverside Woolen Mills, Stafford, Conn.

Riverside Worsted Co., Inc., Woonsocket, R. I.

Robinson Co., J. W., Los Angeles, Calif.

Robinson Manufacturing Co., Oxford, Maine.

Rochambeau Worsted Co., Providence, R. I.

Rockford Mitten \& Hosiery Co., Rockford, Ill.

Rodman Manufacturing Co., La Fayette, R. I.

Rosenbaum Co. of Pittsburgh, Pittsburgh, $\mathrm{Pa}$.

Rosenblums, Los Angeles, Calif.

Royers, Inc., Greensburg, Pa.

Rubenoff \& Son, Robert, New York, N. Y.

Rugby Knitting Mills, Inc., Buffalo, N. Y.

Ruth \& Co., George M., New York, N. Y.

Sachs Co., Nathaniel L., New York, N. Y.

St. Louis Sampling \& Testing Works, St. Louis, Mo.

St. Marys Woolen Manufacturing Co., St. Marys, Ohio. (In principle.)

Salant \& Salant, Inc., New York, N.Y.

Sanford Mills, Sanford, Maine.

Sanger Bros., Inc., Dallas, Tex.

Sanitary Knitting Co., Grand Rapids, Mich.

Santa Ana Woolen Mills, Inc., Santa Ana, Calif.

Saxony Corporation, The, Norwich, Conn.

Scatchard's Sons, Inc., Joseph, Philadelphia, Pa.

Schoonmaker \& Son, Inc., John, Newburgh, N. Y.

Scotch Woolen Mills, Chicago, Ill.

Scotsmoor Co., Inc., Johnstown, N. Y.

Scott \& Sons, Inc., S. F., Uxbridge, Mass.

Scruggs-Vandervoort-Barney, Inc., 'St. Louis, Mo.

Seabright Woven Felt Co., Boston, Mass.

Sears, Roebuck \& Co., Chicago, Ill.

Sheehy Co., Thos. J., Phillips, Maine. 
Sheerr \& Sons, Philip L., Philadelphia, $\mathrm{Pa}$.

Shetucket Worsted Mills, Inc., The, Baltic, Conn.

Skinner \& Sherman, Inc., Boston, Mass.

Smith, Inc., C. G. \& C. A., Allentown, $\mathrm{Pa}$.

Smith Co., Timothy, Boston, Mass.

Smith-Emery Co., Los Angeles, Calif.

Smith-Roberts Co., Griffin, Ga.

Snell, Inc., Foster D., Brooklyn, N. Y.

Somersworth Textile Co., Inc., Somersworth, N. H.

Somerville Knitting Co., Needham, Mass.

South Bend, Better Business Division of, South Bend, Ind. (In principle.)

Southern Worsted Corporation, Boston, Mass.

Springfield Woolen Mills Co., Springfield, Tenn.

Standard Yarn Co., Worcester, Mass.

Star Shawl Co., Inc., Paterson, N. J.

Stevens \& Sons Co., M. T., North Andover, Mass.

Stillman \& Van Siclen, Inc., New York, N. Y.

Stillwater Worsted Mills, Harrisville, R. I.

Stokes Brothers Worsted Co., Inc., Providence, R. I.

Stone Knitting Mills Co., Cleveland, Ohio.

Strong, Hewat \& Co., Inc., North Adams, Mass.

Sulloway Hosiery Mills, Inc., Franklin, N. H.

Sweetwater Woolen Mills, Sweetwater, Tenn.

Swift River Woolen Co., Westerly, R. I.

Sydney Worsted Co., Woonsocket, R. I.

Tavlor Bramley Co., The, Chicopee Falls, Mass.

Terhune, Yereance \& Wolff, Inc., New York, N. Y.

Texas State College for Women, Denton, Tex.

TexKnit Mills, Union City, N. J.

Textile Banking Co., Inc., New York, N. Y. (In principle.)

Textile Novelty Shop, Putnam, Conn.

Textile Testing \& Research Laboratories, New York, N. Y.

Thermo Mills, Inc., Hudson, N. Y.

Thompson \& Lichtner Co., Inc., The, Boston, Mass.

Tipper \& Co., F. W., New York, N. Y. (In principle.)

Twining Laboratories, The, Fresno, Calif.

Union Knitting Mills, Inc., Schuylkill Haven, Pa.

Union Manufacturing Co., Frederick, Md.

United States Testing Co., Inc., Hoboken, N. J.

Utica Wadding Co., Inc., Bronx, N. Y.
Valentine Co., L. Morgan, New York, N. Y.

Van Cleve Laboratories, Inc., Minneapolis, Minn.

Vaughn Woolen Mill, Willis, Va.

Verd Mont Woolen Mills, Inc., Ludlow, $\mathrm{Vt}$.

Vermont Woolen Mills, Inc., New York, N. Y.

Vreeland, D. R., New York, N. Y.

Walther Manufacturing Co., Inc., Philadelphia, $\mathrm{Pa}$.

Wanskuck Co., Providence, R. I.

Warren Woolen Co., The, Stafford Springs, Conn.

Wasson \& Co., H. P., Indianapolis, Ind.

Waterville Textile Mills, Inc., Waterville, N. Y.

Watt Woolen Co., Geo. W., Norristown, Pa.

Wavne Knitting Mill, Philadelphia, Pa.

Welek \& Co., Inc., Chas. F., St. Louis, Mo.

West Bend Woolen Mills Co., West Bend, Wis.

Whitaker Co., Fred, Philadelphia, Pa.

Whittaker \& Sons, Inc., James, Oxford, Mass.

Wiedemann, H. E., St. Louis, Mo.

Wiley Dry Goods Co., The, Hutchinson, Kans.

Wilson Brothers, Chicago, Ill.

Wilton Woolen Co., Wilton, Maine.

Winchester Woolen Co., Inc., Winchester, Va.

Windsor Manufacturing Co., Philadelphia, Pa.

Wister Spinning Co., Inc., Germantown, Philadelphia, $\mathrm{Pa}$.

Wittenberg Mills, Inc., Cedarburg, Wis.

Worcester Textile Co., Inc., Greystone, R. I.

Worth Brothers, Inc., Los Angeles, Calif.

Worumbo Manufacturing Co., Lisbon Falls, Maine.

Wright Textile Co., Philadelphia, Pa.

Wuskanut Mills, Inc., The, Farnumsville, Mass.

Wynantskill Manufacturing Co., Troy, N. Y.

Yale Woolen Mills, Yale, Mich.

Young Department Store Co., Inc., Mattoon, Ill.

Ziock Industries, Inc., Rockford, Ill.

\section{U. S. GOVERNMENT}

Agriculture, Department of, Division of Purchase, Sales \& Traffic, Washington, D. C.

Office of Price Administration, Standards Division, Washington, D. C. (In principle.)

Treasury Department, Washington, D. C. Veteran's' Administration, Washington, D. C. 


\section{COMMERCIAL STANDARDS}

CS No.

$0-40$. Commercial standards and their value to business (third edition)

1-42. Clinical thermometers (third edition).

2-30. Mopsticks.

$3-40$. Stoddard solvent (third edition).

4-29. Staple porcelain (all-clay) plumbing fixtures.

5-40. Pipe nipples; brass, copper, steel, and wrought iron.

6-31. Wrought-iron pipe nipples (second edition). Superseded by CS5-40.

7-29. Standard weight malleable iron or steel screwed unions.

8-41. Gage blanks (third edition)

9-33. Builders' template hardware (second edition.)

10-29. Brass pipe nipples. Superseded by CS540.

11-41. Moisture regains of cotton yarns (second edition).

12-40. Fuel oils (fifth edition).

13-42. Dress patterns (third edition).

14-39. Boys' button-on waists, shirts, junior and polo shirts (made from woven fabrics) (second edition).

(E)15-43. Men's pajamas (made from woven fabrics) (second edition).

16-29. Wall paper.

17-42. Diamond corc drill fittings (third edition).

18-29. Hickory golf shafts.

19-32. Foundry patterns of wood (second edition).

20-42. Staple vitreous china plumbing fixtures (third edition)

21-39. Interchangeable ground-glass joints, stop cocks, and stoppers (fourth edition)

22-40. Builders' hardware (nontemplate) (second edition).

23-30. Feldspar.

24-43. Screw threads and tap-drill sizes.

25-30. Special screw threads. Superseded by CS24-43.

26-30. Aromatic red cedar closet lining.

27-36. Mirrors (second edition).

28-32. C o t t o n fabric tents, tarpaulins, a n d covers.

29-31. Staple seats for water-closet bowls.

30-31. Colors for sanitary ware.

31-38. Wood shingles (fourth edition).

$32-31$. Cotton cloth for rubber and pyroxylin coating.

33-32. Knit underwear (exclusive of rayon)

34-31. Bag, case, and strap leather.

35-42. Plywood (hardwood and eastern red cedar) (second edition).

36-33. Fourdrinier wire cloth (second edition)

37-31. Steel bone plates and screws.

38-32. Hospital rubber sheeting.

39-37. Wool and part wool blankets (second edi tion). (Withdrawn as commercial standard, July 14, 1941.)

40-32. Surgeons' rubber gloves.

41-32. Surgeons' latex gloves.

42-35. Fiber insulating board (second edition)

43-32. Grading of sulphonated oils.

44-32. Apple wraps.

45-42. Douglas fir plywood (fifth edition).

46-40. Hosiery lengths and sizes (third edition)

47-34. Marking of gold-filled and rolled-goldplate articles other than watchcases.

48-40. Domestic burners for Pennsylvania anthracite (underfeed type) (second edi. tion).
CS No.

Item

49-34. Chip board, laminated chip board, and miscellaneous boards for bookbinding purposes.

50-34. Binders board for bookbinding and other purposes.

51-35. Marking articles made of silver in combination with gold.

52-35. Mohair pile fabrics (100-percent mohair plain velvet, 100-percent mohair plain frieze, and 50-percent mohair plain frieze).

53-35. Colors and finishes for cast stone.

54-35. Mattresses for hospitals.

55-35. Mattresses for institutions.

56-41. Oak flooring (second edition).

57-40. Book cloths, buckrams, and impregnated fabrics for bookbinding purposes except library bindings (second edition).

58-36. Woven elastic fabrics for use in overalls (overall elastic webbing)

59-41. Woven textile fabrics-testing and reporting (third edition)

60-36. Hardwood dimension lumber.

61-37. Wood-slat venetian blinds.

62-38. Colors for kitchen accessories.

63-38. Colors for bathroom accessories.

64-37. Walnut veneers.

65-43. Methods of analysis and of reporting fiber composition of textile products (second edition).

66-38. Marking of articles made wholly or in part of platinum.

67-38. Marking articles made of karat gold.

68-38. Liquid hypochlorite disinfectant, deodorant, and germicide.

69-38. Pine oil disinfectant.

70-41. Phenolic disinfectant (emulsifying type) (second edition) (published with CS7141).

71-41. Phenolic disinfectant (soluble type) (second edition) (published with CS70-41)

72-38. Household insecticide (liquid spray type)

73-38. Old growth Douglas fir standard stock doors.

74-39. Solid hardwood wall paneling.

75-42. Automatic mechanical draft oil burners designed for domestic installations (second edition).

7f-39. Hardwood interior trim and molding.

77-40. Sanitary cast-iron enameled ware.

78-40. Ground-and-polished lenses for sun glasses (second edition) (published with CS79$40)$.

79-40. Blown, drawn, and dropped lenses for sun glasses (second edition) (published with CS78-40).

80-41. Electric direction signal systems other than semaphore type for commercial and other vehicles subject to special motor vehicle laws (after market).

81-41. Adverse-weather lamps for vehicles (after market).

82-41. Inner-controlled spotlamps for vehicles (after market).

83-41. Clearance, marker, and identification lamps for vehicles (after market)

84-41. Electric tail lamps for vehicles (after market).

85-41. Electric license-plate lamps for vehicles (after market)

86-41. Electric stop lamps for vehicles (after market).

87-41. Red electric warning lanterns.

88-41. Liquid-burning flares. 
CS No

Item

CS No.

Item

89-40. Hardwood stair treads and risers.

90- . (Reserved for power shovels and cranes).

91-41. Factory fitted Douglas fir entrance doors.

92-41. Cedar, cypress and redwood tank stock lumber.

93-41. Portable electric drills (exclusive of high frequency).

94-41. Calking lead.

95-41. Lead pipe.

96-41. Lead traps and bends.

97-42. Electric supplementary driving and passing lamps for vehicles (after market).

98-42. Artists' oil paints.

99-42. Gas floor furnaces-gravity circulating type.

utensils.
101lue-connected oil-burning space heater equipped with vaporizing pot-type burners.

102- . (Reserved for Diesel and fuel-oil engines) 103-42. Cotton and rayon velour (jacquard and E) 104-43. plain).

plain). izing pot-type oil burners.

105-43. Mineral wool; loose, granulated, or felted form, in low-temperature installations.

(E)106-43. Boys' pajamas (made from woven fabrics).

(E) 107-43. Commercial electric refrigeration condensing units.

Notice.-Those interested in commercial standards with a view toward accepting them as a basis of everyday practice may secure copies of the above standards, while the supply lasts, by addressing the Division of Trade Standards, National Bureau of Standards, Washington, D. C. 